\title{
The Influence of Giving Sweet Potato Leaf Boiled Water to the Acceleration of Breastmilk Production in Nursing Mothers in the Kuta Baro Health Center, Aceh Besar, Indonesia
}

\author{
Maharani Maharani ${ }^{1 \star}$, Nurbaiti Nurbaiti ${ }^{2}$, Lia Lajuna ${ }^{1}$, Yulia Fitri ${ }^{1}$, Putri Santi ${ }^{1}$, Sutrisno Sutrisno ${ }^{2}$ \\ ${ }^{1}$ Department of Midwifery, Polytechnic of Health, Ministry of Health, Aceh, Indonesia; ${ }^{2}$ Department of Obstetrics and Genecology, \\ Universitas Brawijaya, Malang, Indonesia
}

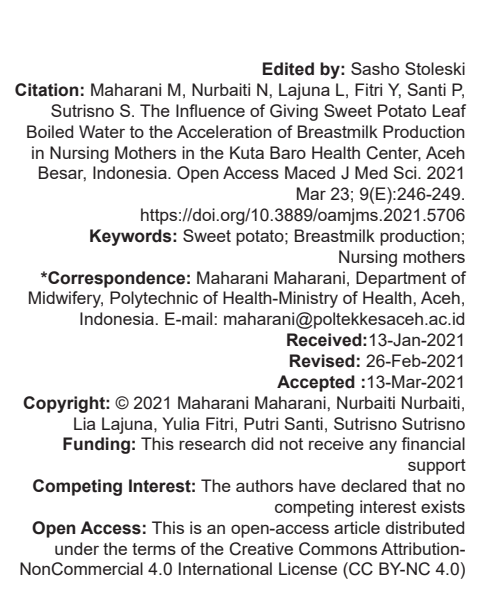

\begin{abstract}
BACKGROUND: Breastmilk (ASI) is the best food for babies. Adequacy of breast milk plays a vital role in the process of growth and development of babies. One way that can be done to increase the rate of secretion and production of breast milk is by giving boiled water for sweet potato leaves.

AIM: The aim of the study was to analyze the effect of giving boiled sweet potato leaves on the acceleration of milk production in nursing mothers.

METHODS: The research design used in this study was pre-experimental with a pretest-posttest design. This research was conducted in the Kuta Baro Health Center, Kuta Baro District, Aceh Besar District and was carried out in May 2020-August 2020. This study's population was all mothers who were breastfeeding and had babies aged 0-6 years. This study sample was part of breastfeeding mothers who had babies aged 0-6 months, selected by purposive sampling as much as 32. Data analysis was performed using the Chi-square statistical test.

RESULTS: The results showed that there was an effect of intervention giving sweet potato boiled water for 5 days with an increase in the acceleration of breast milk production by $204.69 \mathrm{ml}$, and on the $10^{\text {th }}$ day, it was $212.88 \mathrm{ml}$ Furthermore, the intervention of giving boiled water for sweet potato leaves on days 11-15, there was an increase in the average milk production by $214.25 \mathrm{ml}$. These results are evidenced by statistical tests where is a significant difference in acceleration of milk production between before the intervention and after the intervention on the $5^{\text {th }}$ $10^{\text {th }}$, and $15^{\text {th }}$ day $(p<0.05)$
\end{abstract}

CONCLUSION: There is an effect of giving boiled sweet potato leaves water on the acceleration of milk production in breastfeeding mothers in the working area of the Kuta Baro Health Center, Kuta Baro District, Aceh Besar District.

\section{Introduction}

Breast milk is the only food that contains all the nutrients needed for a baby's growth from birth to 6 months of age. Breast milk itself is considered the best source of infant nutrition [1]. Further studies have shown that breast milk reduces infant programs against advanced metabolic disease, significantly protecting against obesity and type 2 diabetes [2]. Breastfeeding is one of the global strategies to improve infants' growth, development, health, and survival [3]. In Indonesia, the percentage of babies who are exclusively breastfed fluctuates. Various factors cause the cessation of exclusive breastfeeding practices, factors related to mother, baby, and environment. Globally, mothers from various socio-environmental contexts often perceive a slow-growing baby associated with inadequate milk supply or low milk quality [4]. These assumptions often encourage breastmilk replacement with formula or other non-breastfed foods to encourage weight gain and length of the baby [4]. However, the most common inhibiting factors leading to failure of exclusive breastfeeding before the first 6 months of life are breastfeeding factors that have not been released or insufficient milk production [5], [6]. The reason for giving it is because the milk that comes out is still very little, and the baby often cries. That mothers' most frequent reasons to stop breastfeeding between the $1^{\text {st }}$ month and the $2^{\text {nd }}$ month were that babies had difficulty in sucking and improper attachment; Breast milk alone is no longer enough for the baby; and not enough breast milk [7]. That the factor of breastfeeding that has not come out or inadequate milk production is the most common factor for providing substitutes or substitutes for breast milk so that there is a failure in exclusion breastfeeding [8].

Another factor is inadequate knowledge of mothers about the benefits of breastfeeding and a lack of family support. The study in West Java showed that $32.2 \%$ of the 609 respondents claimed to have been given palatial fluids in the form of formula milk by health workers at delivery homes because the milk had not yet been released [9]. One way that can be done to increase the rate of secretion and production of breast 
milk is by giving boiled water for sweet potato leaves. For a long time, sweet potato leaves are believed to be used as herbal medicines to increase milk production. Sweet potato leaves are healthy vegetables that are rich in antioxidants [10]. Sweet potato leaves or vegetables (Ipomoea batatas) are generally consumed as vegetables, especially in Asian countries [11]. Sweet potato leaves contain galactagogue substances that can increase milk production. Sweet potato leaves also contain carotenoids and iron. For this reason, the purpose of this study is to analyze the effectiveness of the consumption of sweet potato leaves on the speed of milk production in the Kuta Baro Health Center, Kuta Baro District, Aceh Besar District.

\section{Methods}

The research design used in this study was preexperimental with a pretest-posttest design. This research was conducted in the Kuta Baro Health Center, Kuta Baro District, Aceh Besar District and was carried out in May 2020-August 2020. This study's population was all mothers who were breastfeeding and had babies aged 0-6 years. In this study, the sample was some of the breastfeeding mothers who had babies aged 0-6 months, which were selected by purposive sampling as many as 32 people. The independent variable in this study was the provision of boiled water for sweet potato leaves. The dependent variable is the acceleration of milk production. Data analysis was performed using the Chi-square statistical test.

\section{Results}

The following are the respondents characteristics based on the acceleration of milk production before being given boiled sweet potato leaves to breastfeeding mothers. The results showed that all respondents $(100 \%)$ admitted that breast milk was still reduced before being given the sweet potato leaf stew. After giving boiled water for sweet potato leaves, there is an accelerated increase in breast milk production.

Based on Table 1 shows that the acceleration of milk production before giving boiled water for sweet potato leaves have an average value of $192.50 \mathrm{ml}$.
After intervention to provide boiled sweet potato water for 5 days, the acceleration of breast milk production increased by $204.69 \mathrm{ml}$, and on the $10^{\text {th }}$ day, it was $212.88 \mathrm{ml}$. Furthermore, the intervention was giving boiled water for the last 5 days, namely the $11^{\text {th }}$ to the $15^{\text {th }}$ day; the average milk production from the intervention increased to $214.25 \mathrm{ml}$.

Based on Table 2, it is known that there is a significant difference $(p<0.05)$ in the acceleration of breast milk production before the intervention and after the intervention was given boiled water for sweet potato leaves on the $5^{\text {th }}, 10^{\text {th }}$, and $15^{\text {th }}$ day.

\section{Discussion}

Discussion based on the research results, all respondents know that after being given boiled water of sweet potato leaves, breast milk production experienced an increase in breast milk production. The intervention was giving boiled sweet potato water for 5 days, the acceleration of milk production increased by $204.69 \mathrm{ml}$, and on the $10^{\text {th }}$ day, it was $212.88 \mathrm{ml}$. Furthermore, the intervention was giving boiled water for the last 5 days, namely the $11^{\text {th }}$ to the $15^{\text {th }}$ day, the average milk production from the intervention. It increased to $214.25 \mathrm{ml}$. There was a significant difference $(p<0.05)$ between the acceleration of breast milk production before giving boiled water for sweet potato leaves and after the intervention on day 5 , day 10 , and day 15 . Proper infant nutrition promotes healthy growth and development and lowers disease risk later in life [12]. Also found that the leaves had the highest phenolic acid content than the bark and roots of the three sweet potato varieties [13]. Sweet potatoes can improve Vitamin A status, increase the bioavailability of various micronutrients such as $\mathrm{Fe}, \mathrm{Zn}, \mathrm{Ca}$, and $\mathrm{Mg}$, reduce Vitamin A deficiency, and reduce child mortality by $23 \%$ to $30 \%$ [14]. Sweet potato leaves contain Vitamin A, besides provitamin A (beta carotene), B and C, iron, calcium, phosphorus, and fat. Its production is significant in the process of lactation/ breastfeeding. The adequate milk supply for the baby, the more successful the breastfeeding process is and vice versa. The process of accelerating breast milk production is obtained by consuming boiled sweet potato leaves regularly, namely, every three times a day for 15 days, with $250 \mathrm{~g}$ of sweet potato leaves every day during the breastfeeding process. Sweet potato

Table 1: Results of the analysis of the effect of accelerated breast milk production before and after giving boiled sweet potato leaves to nursing mothers in the working area of health center

\begin{tabular}{|c|c|c|c|c|c|c|c|}
\hline Breastmilk production & $\mathrm{n}$ & Minimum & Maximum & Mean & SD & $95.0 \%$ lower $\mathrm{CL}$ for mean & $95.0 \%$ upper $\mathrm{CL}$ for mean \\
\hline \multicolumn{8}{|l|}{ Pre (before giving boiled sweet potato leaves) } \\
\hline Before giving boiled water, sweet potato leaves & 32 & 140 & 240 & 192.50 & 25.273 & 183 & 202 \\
\hline \multicolumn{8}{|l|}{ Post (after giving boiled sweet potato leave) (days) } \\
\hline $1-5$ & 32 & 170 & 280 & 204.69 & 24.228 & 196 & 213 \\
\hline $6-10$ & 32 & 192 & 280 & 212.88 & 20.840 & 205 & 220 \\
\hline $11-15$ & 32 & 188 & 280 & 214.25 & 22.966 & 206 & 223 \\
\hline
\end{tabular}


Table 2: Results of the analysis of the effect of providing water with sweet potato leaves on the acceleration of breastfeeding production in breastfeeding mothers in the work area of health center

\begin{tabular}{lccccc}
\hline Breastmilk production & Mean & $\mathrm{n}$ & $\chi^{2}$ & $\mathrm{df}$ & $\mathrm{p}$ \\
\hline Pre (before giving boiled sweet potato leaves) & & & & & \\
$\quad$ Before giving boiled water, sweet potato & 1.80 & 32 & 18.135 & 3 & 0.000 \\
$\quad$ leaves & & & & & \\
Post (after giving boiled sweet potato & & & & & \\
leaves) (days) & 2.38 & 32 & & & \\
$1-5$ & 2.91 & 32 & & & \\
$6-10$ & 2.92 & 32 & & & \\
$11-15$ & & & & \\
\hline
\end{tabular}

leaves or vegetables rich in $B$ vitamins, $\beta$-carotene, iron, calcium, and zinc, green sweet potato (SPG) is very nutritious and contains many vitamins, minerals, and other nutrients [15]. Sweet potato leaves are an excellent source of antioxidant polyphenols, namely anthocyanins and phenolic acids such as caffeic acid, monocaffeoylquinic (chlorogenic), caffeoylquinic, and tricaffeoylquinic [16], [17]. Higher consumption of SPG is associated with a reduced risk of lung cancer [18]. There are no specific recommendations regarding the optimal amount or group of food that children should consume, but a more diverse variety of food items will help meet various nutrients' daily needs [19]. The form of ready-to-eat products developed in this study can also be an alternative food supplement for breastfeeding mothers who work outside the home. The implication for further research is the need to study the galactagogue mechanism of the phytochemical compounds from the resulting Torbangun flour and further studies on the product's shelf life. The supplementary food products produced from this study can also be used to supplementary food for nursing mothers in emergencies such as natural disasters. Furthermore, it was revealed that the knowledge, beliefs, and behaviors were carried out due to a lack of awareness of the benefits and risks of not practicing breastfeeding as recommended. Most mothers can successfully breastfeed their babies exclusively if they have support and guidance on proper breastfeeding practice and are supported to do it right.

\section{Conclusion}

Based on the research results, it is known that there is an effect of giving boiled water of sweet potato leaves on the acceleration of breast milk production in nursing mothers in the working area of the Kuta Baro Health Center, Kuta Baro District, Aceh Besar District.

\section{References}

1. Lessen R, Kavanagh K. Position of the academy of nutrition and dietetics: Promoting and supporting breastfeeding. J Acad Nutr
Diet. 2015;115(3):444-9. https://doi:10.1016/j.jand.2014.12.014 PMid:25721389

2. Savino F, Benetti S, Liguori SA, Sorrenti M, Di Montezemolo LC. Advances on human milk hormones and protection against obesity. Cell Mol Biol (Noisy-le-Grand). 2013;59(1):89-98.

PMid:24200024

3. World Health Organization. Exclusive Breastfeeding for Six Months Best for Babies Everywhere. Geneva: World Health Organization; 2011.

4. Gatti L. Maternal perceptions of insufficient milk supply in breastfeeding. J Nurs Scholarsh. 2008;40(4):355-63. https:// doi:10.1111/j.1547-5069.2008.00234.x

PMid: 19094151

5. Turkyılmaz C, Onal E, Hirfanoglu IM, Turan O, Koç E, Ergenekon $\mathrm{E}$, et al. The effect of galactagogue herbal tea on breast milk production and short-term catch-up of birth weight in the first week of life. J Altern Complement Med. 2011;17(2):13942. https://doi:10.1089/acm.2010.0090

PMid:21261516

6. Hue SM, Boyce AN, Somasundram C. Antioxidant activity, phenolic and flavonoid contents in the leaves of different varieties of sweet potato (Ipomoea batatas). Aust J Crop Sci 2012;6:375.

7. Li R, Fein SB, Chen J, Grummer-Strawn LM. Why mothers stop breastfeeding: Mothers' self-reported reasons for stopping during the first year. Pediatrics. 2008;122(Suppl 2):S69-76. https://doi:10.1542/peds.2008-1315i

PMid:18829834

8. Haider R, Rasheed S, Sanghvi TG, Hassan N, Pachon H, Islam $\mathrm{S}$, et al. Breastfeeding in infancy: Identifying the programrelevant issues in Bangladesh. Int Breastfeed J. 2010;5:21. https://doi:10.1186/1746-4358-5-21

PMid:21118488

9. Hidayat TS, Hermina $\mathrm{H}$, Afriansyah N. Hubungan konsumsi makanan ibu selama kehamilan dan pemberian asi pertama kali setelah melahirkan (Association of maternal food consumption during pregnancy and the first time breastfeeding after delivery). Nutr Food Res. 2010;33(2):223502.

10. Lee SL, Lee HK, Chin TY, Tu SC, Kuo MH, Kao MC, et al Inhibitory effects of purple sweet potato leaf extract on the proliferation and lipogenesis of the 3T3-L1 preadipocytes. Am J Chin Med. 2015;43(5):915-25. https://doi:10.1142/ S0192415X15500536

PMid:26205968

11. Mosha TC, Gaga HE. Nutritive value and effect of blanching on the trypsin and chymotrypsin inhibitor activities of selected leafy vegetables. Plant Foods Hum Nutr. 1999;54(3):271-83. https:// doi:10.1023/a:1008157508445 PMid:10716408

12. Prell C, Koletzko B. Breastfeeding and complementary feeding Dtsch Arztebl Int. 2016;113(25):435-44. https://doi:10.3238/ arztebl.2016.0435 PMid:27397020

13. Truong VD, McFeeters RF, Thompson RT, Dean LL, Shofran B. Phenolic acid content and composition in leaves and roots of common commercial sweetpotato (Ipomea batatas L.) cultivars in the United States. J Food Sci. 2007;72(6):C343-9. https:// doi:10.1111/j.1750-3841.2007.00415.x PMid: 17995676

14. Gurmu F, Hussein S, Laing M. The potential of orange-fleshed sweet potato to prevent Vitamin A deficiency in Africa. Int J Vitam Nutr Res. 2014;84(1-2):65-78. https://doi:10.1024/0300-9831/ a000194

PMid:25835237 
15. Islam MS, Yoshimoto M, Terahara N, Yamakawa O. Anthocyanin compositions in sweetpotato (Ipomoea batatas L.) leaves. Biosci Biotechnol Biochem. 2002;66(11):2483-6. https://doi:10.1271/ bbb.66.2483

PMid:12506993

16. Kurata R, Adachi M, Yamakawa O, Yoshimoto M. Growth suppression of human cancer cells by polyphenolics from sweetpotato (Ipomoea batatas L.) leaves. J Agric Food Chem. 2007;55(1):185-90. https://doi:10.1021/jf0620259

PMid:17199331

17. Garcia-Salas P, Morales-SotoA, Segura-CarreteroA, FernándezGutiérrez A. Phenolic-compound-extraction systems for fruit and vegetable samples. Molecules. 2010;15(12):8813-26. https:// doi:10.3390/molecules 15128813

\section{PMid:21131901}

18. Jin YR, Lee MS, Lee JH, Hsu HK, Lu JY, Chao SS, et al. Intake of Vitamin A-rich foods and lung cancer risk in Taiwan: With special reference to garland chrysanthemum and sweet potato leaf consumption. Asia Pac J Clin Nutr. 2007;16(3):477-88.

PMid:17704030

19. Ruel MT, Menon P. Child feeding practices are associated with child nutritional status in Latin America: Innovative uses of the demographic and health surveys. J Nutr. 2002;132(6):1180-7. https://doi:10.1093/jn/132.6.1180

PMid:12042431 